\title{
The Role of Information and Communication Technologies in the Teaching and Learning of History
}

\author{
Anastasia D. Vakaloudi ${ }^{1}$, Vasileios Dagdilelis ${ }^{2}$ \\ ${ }^{1}$ Teachers' Supervisor in Secondary Education (Linguistics, Literature, History) - Ministry of Education \\ Greece \\ anvakaloudi@yahoo.gr \\ ${ }^{2}$ Professor, Department of Educational and Social Policy \\ University of Macedonia \\ Greece \\ dagdil@uom.gr
}

\begin{abstract}
This paper is based on the findings that arose from history lessons that took place within the context of a research study carried out on a diverse student population at various Secondary Schools (Junior and Senior High Schools). The objective of this research was to examine the effectiveness of history teaching methods employing Information and Communication Technology (ICT) in comparison to other traditional methods that were applied during the learning process.
\end{abstract}

Keywords: ICT, School Education, Learning

Received: 17 September 2018, Revised 9 November 2018, Accepted 21 November 2018

DOI: $10.6025 / \mathrm{jdp} / 2019 / 9 / 2 / 40-45$

(C) 2019 DLINE. All Rights Reserved

\section{Introduction}

This paper is based on the findings that arose from history lessons that took place within the context of a research study carried out on a diverse student population at various Secondary Schools (Junior and Senior High Schools), within the county of Thessaloniki (Greece), during the school years 2009-2011. The objective of this research was to examine the effectiveness of history teaching methods employing Information and Communication Technology (ICT) in comparison to other traditional methods that were applied during the learning process [1]. The findings and conclusions that will be presented arise from history lessons that took place in classes of students in a variety of schools, in the Computer Science Laboratories, where the children worked in teams using computer terminals or in classrooms. In general, the lessons were designed so that they could furthermore be conducive to the following objectives: the cultivation of new literacy, technological and digital literacy or techno-literacy, the social extent of which is very broad - a fact that cannot be overlooked by schools. The content of this new literacy could be focused on: the cultivation of information search strategies, the ability to pinpoint a specific piece of information 
- an important part of which includes the ability to assess its validity, the technique of scanning a text using distinct Internet grammar (hypertext), the techniques relating to organizing information that has been found and using it when carrying out specific projects - for instance, incorporating this information into written and oral discourse. The lessons, findings, and general research that are presented in this proposal were part of a wider research project that was implemented and which aimed to investigate the educational use of ICT when teaching History as well as provide relevant phrasing of educational recommendations.

\section{Digital Material and the Theoretical Framework of its use}

\subsection{The Teaching of History}

The Teaching of History is defined as the students' cultivation of skills and abilities, which a historian has, such as historical understanding, adaptation, analysis, synthesizing [2]. Contemporary teaching highlights, as the primary objective of History, historical understanding which is based on knowledge of the content of history, the methods of approaching historical fact and the understanding of concepts (evidence, cause, explanation, empathy, etc.) that seem to play a crucial role in history understanding [3]. Therefore, in teaching History, a crucial role is played by:

1) Comprehensive History (New History, Microhistory, Oral History, etc.);

2) The experiential relationship with the past through meaningful communication, collaboration, common reflection and pursuit, interaction, cognitive conflict within existing knowledge and knowledge which is being acquired;

3) A critical approach to sources and historiographical works;

4) Historical interpretation which is based on logic and facts.

\subsection{The contribution of Information and Communication Technologies (ICT) to teaching History}

The basic precept of constructivism is that learning is achieved via the mediation of tools and work [4]. ICT as a tool for teaching History can substantially alter the way that students access, gather, analyse, reconstruct, present and convey information. There are at least 5 main reasons that advocate the integration of ICT in the learning process and they relate to the support and reinforcement of: (a) learning; (b) teaching; (c) the socialization of the child; (d) the social inclusion of children with learning difficulties; (e) the creativity and effectiveness of the educators [5]. In particular, ICT can substantially contribute to the teaching of History because:

1) It can provide access to primary and secondary sources;

2) It can cultivate a kind of experience in students, with simulations, videotapes, sound recordings etc., which make the understanding of historical terms, concepts and facts feasible;

3) It favours the creation of an exploratory and collaborative learning environment;

4) It offers rich visual material to the teacher, which complements the material in the school textbooks [6].

\section{Didactic Approach and Methodology}

We utilize in the organisation of teaching:

1) Critical social theory. The reflexive dialectical perspective of critical social theory tends to see practice from the perspective of the insider group, whose members' interconnected activities constitute and reconstitute their own social practices, in the first person (plural) [7]. Following this method, the researcher collaborated with the teachers and students who participated in the research, with discourse and critical reflection [8]. In this particular research, therefore, we implemented techniques of educational action research, i.e. the participation of teachers was equal in the decision-making process, in the selection, design and development of the entire action [9].

2) Computer Supported Collaborative Learning (CSCL).

This theory is concerned with the improvement of teaching and learning with the assistance of ICT (the promotion of collaborative 
interaction between the members of a group and the facilitation of the sharing and the dissemination of knowledge). The objective was the study of the teaching process and learning outcomes which emerged from the teachings and how that changed because of student involvement in the topic, the project method, the interdisciplinary approach, group/collaborative effort and the help of ICT. Another objective was the study of the abilities, skills, attitudes and behaviours that were cultivated and developed by the students and teachers within a learning environment with the above-mentioned features. Through this, we reached the findings that we present.

For the collection and analysis of data, techniques of content analysis were used, among others. The basic aim of analysing content is the method of categorization. Categorization is created through observing objects, things, situations which have a certain number of common characteristics by qualitative criteria and constitute "categories" [10].

Therefore, following this procedure, we observed and analysed:

i) The data from lesson transcripts, i.e. the participation of students in exploratory activities for the collection of their material, in problem-solving processes, in participatory and collaborative activities, in activities for the creation of their assignments, the things they declare that they themselves felt and experienced, as well as the informal discussions with the teachers and teacherspectators that were observing the lessons.

ii) The worksheets which entailed different activities therefore different choices in processing the material for each group, and categories of questions for the exploration of historical material through ICT.

iii) The oral and/or written assignments that the students presented in the open plenary session of the class and namely the ways of expressing and presenting their results. We counted how often a category of data was reiterated. By counting the frequency of each category (its reiteration, i.e. by different people), aggregated results arose. From the process of repeated readings and synthesized categories, we ended up in data categories which were grouped according to their interconnections and properties, in this way shaping a basic theoretical frame of thematic axes which formed the basis of the final findings.

\section{Findings}

The most significant findings from the analysis of the data which was collected in the course of these lessons, can be summarized as follows:

i) During the lessons students investigated, either in groups or individually, the relevant educational material and analysed historical topics with the help of the worksheets with different activities, hence different options for processing the material for each group.

Investigation as a means of utilizing historical sources was also chosen. The students worked with primary and secondary sources, based on the fact that the value of historical sources for the teaching of History is significant [11]. In addition, the internet was utilized, which is a potential reservoir of digital content.

ii) At the same time, the students were brought to understand concepts such as place and time by using maps as tools for studying history for the elicitation of historical conclusions.

Levstik and Barton [12] define historical empathy as being a "process of understanding people in the past by contextualizing their actions". In the historical context, the concept of empathy is a deep understanding of the circumstances and concepts surrounding the event. Therefore, there would need to be an idea of the time and place in which the event occurred. With the understanding of place and time and the use of maps, students realized the essential relationship of History and Geography and that the map itself provides basic information as to time and geographical place in which narrated historical events take place with which we are able to study and interpret some of the historical events [13].

iii) The students showed interest, enjoyment, dealt with their topic, discussed, thought, considered, created original work which they substantiated and presented in the open plenary session of the class.

The students used educational software, websites and search engines (with key words) for the investigation of historical topics, electronic dictionaries in order to look up the definitions of various concepts, electronic tools for recording notes such as "Notepad," conceptual maps for the graphic correlation of concepts, "Electronic Text Corpora" to find texts relevant to the research topic. They practiced organizing and categorizing data in databases. With data from the internet, they analyzed

J2 Journal of Data Processing Volume 9 Number 2 June 2019


artwork, i.e. they interpreted it based on the characteristics of the art it represented (e.g. Renaissance or Romanticism). For the interpretation of artwork, they used corresponding concepts (in the case of Renaissance art "mythology, Christianity, beauty, man, etc."). They selected the appropriate visual material to support the oral part of their presentation, or their written statement creating an original script and/or multimodal text. In all the lessons, the students' pleasure and satisfaction in the learning process was evident.

\section{iv) The students" "journey" is significant up to the start of the essential part of the lesson (versus teaching time).}

It was observed, specifically, that the teaching method which was applied made a difference in the learning climate from the 5th to 8th minute. Silence and order start to prevail in the class. The students are interested and participate. In the 9th minute, a commotion which lasts a few minutes is noted. The students are unfamiliar with group collaborative, inquiry-based learning and thus require a period to adapt. However, their active involvement in the learning process is observed. Hesitation is minimized and they try to make use of their vocabulary in order to willingly participate, expressing their points of view and opinions, through the observation of maps, archaeological findings, artwork and texts that were processed. In the 10th to 12th minute, the atmosphere changes and there is silence, order, the students' interest is stimulated in order to actively participate and work together. We observe a change in the students' attitude to a collaborative, exploratory one. In the 15 th minute the processing of sources begins. The students are accustomed to the exam-based method. They are fully responsive to asking why and giving mechanical, memorized answers to questions. In this way, they appear to be momentarily puzzled in relation to the learning process of investigating and solving problems. However, with the help of ICT, which provided the possibility of inquiry-based, individual and/or collaborative learning, the students actively participate in the process. From the 20th minute the atmosphere changes completely. The students experience the joy of discovery, participate creatively and observe that the verification of information via personal research leads to different pathways of choosing tack and gives various possibilities for the interpretation of historical data. In a microanalysis of one school, we observe that in the 20th and 22nd minute, isolated incidents of misbehaviour arise. However, they are manageable. Even the students resent and complain about the fuss that their classmates make.

v) A role-play was put into practice, which was enjoyable and creative for the students.

In one reality simulation (an exercise on ways to do historical research), the students: Took on the role of an archaeologist who is carrying out an excavation or a historian who is poring over historical sources, in order to reach historical conclusions; took on the role of an art or literary critic, in order to study the artistic or literary themes in combination with the corresponding historical period; took on the role of a writer or journalist ect. In this way, they activated their imagination and empathy [14]. In addition, they took on roles within the group, in order to coordinate and carry out assignments. All this was aimed at furthering the research.

vi) There was a significant difference in the behaviour and participation of students and the understanding of concepts between the two teaching methods, the usual teacher-centered one and the one that we recommend. During the teaching process, teaching methods suitable for children with learning difficulties were applied and reinforced an important part of their education, their self-confidence.

Most of the schools where the lessons took place have the following characteristics:

a) A large percentage of immigrant children;

b) A large percentage of Romany children;

c) A large percentage of students (Greek, Romany and immigrant children) from the lower economic and social strata.

All of the above-mentioned students have learning problems, family problems, are lower-level learners. Their problems learning are similar to those of children with learning difficulties.

Consequently, the lessons were specifically aimed at supporting these students, as well as students with learning difficulties. So topics were dealt with by asking questions, skills were cultivated for collaborative learning and the value of group collaboration and teaching among peers (peer teaching) emerged. They were assigned tasks with pictures, without many details. The information was presented in written format, with maps, tables, pictures, to increase their ability to understand and memorize the information. The students could use alternative ways, e.g. they could do their writing on the computer, which has been proven to help children with learning difficulties. They used assistive technology (e.g. spellcheck and the computer's dictionary), recorded their notes; the method of recording notes teaches them to reorganise information into a more understandable and useful format. Note-taking is a cognitive skill of active learning. Group readings were organised, the main points of the topic were highlighted 
as a comprehension exercise. The tasks had to be realised within a set time period, by delegating parts of the work to group members. Particular attention and emphasis was placed on boosting the selfesteem of students, mainly by presenting their work in the open plenary session of the class, either orally or in writing.

viii) After collecting, observing, categorizing and studying the material, the groups were asked to discuss and to draw conclusions from their findings, by consulting their notes and making arguments through oral, and/or written, multimodal expression.

The students used MS Office to compose a historical calendar of events or to fill in a mindmap and to then compose a short text for publication in their school newspaper for the presentation of Maritime archaeology, to take notes commenting on oral historical events, to categorize in databases archaeological findings according to specific criteria, to create multimodal texts and so to present the answers to the exploratory historical questions with the data and information that they collected etc. With presentation software, they organised historical information and related them with others (textmap, map-data table, text-picture etc). They grasped, in this way, the array of historical sources and their combined study, in order to extract historical conclusions.

\section{ix) There was a substantial change in the role of teachers.}

The teaching practice of the teachers was one that highlighted the added value of ICT and support for the students, to reconstruct historical facts and construct their own historical interpretations. The teachers had the role of coordinator/mentor, designer of activities. Initially they organized the lesson, set goals, prepared research projects, planned WebQuests, the scope of activities, the worksheets with different activities, therefore different processing options of the material for each group, with email addresses and the remaining material. Then, they implemented collaborative learning in groups, which worked flawlessly. They organised the class into two-member, three-member or four-member groups, and presented the material in electronic format. The questions that were posed by the teachers were aimed at "forcing" the students to deal with, discuss, think, analyse, the goal was to further the research. Learning was transformed from a behavioural to a cognitive process, from a static situation to a dynamic one.

\section{Summary and Conclusions}

The data that we collected show that the students had much greater personal involvement in the processing of the topic that we proposed, than what they would have had in traditional teaching. The objectives that were accomplished were:

a) To carry out group-collaborative exploration of information given by the school textbook, through Information and Communication Technologies (ICT), to make it more understandable and accessible to children;

b) to make the students aware: (i) that maps are tools for studying History, from which we can draw historical conclusions; (ii) the essential relationship between History and Geography and (iii) that the map itself is intended to provide, in addition to time, basic information about geographical place in which the narrated historical events take place.

(c) In the lessons, experiential learning was applied (learning by doing):

An atmosphere of interaction was created, by using objects and tools, tangible (e.g. educational software, the internet, digital tools, worksheets) and symbolic (language, communication, interaction, cooperation between teachers and students, and students amongst themselves). Depending on the educational environment, investigation and learning are enabled through action and are interactive [15]. The students practised types of historical research with roleplaying games. Through the observation and study of various materials, students drew conclusions, which they used to make arguments, responding to different research questions, either orally or in writing, in collaboration with others in group projects.

\section{References}

[1] Vakaloudi, A. D. (Teaching and Learning with the use of ICT. Theory \& Practice). p. 28, 29. Athens. 2003. In Greek.

[2] Levstik, L. S., Barton, K. C. (2011). Doing history: Investigating with children in elementary and middle schools. Routledge. 2011.

[3] Limón, M. (2002). Conceptual Change in History, in: M. Limón \& S. Mason, (eds), Reconsidering Conceptual Change: Issues 
in Theory and Practice. p. 259-289. Dordrecht. 2002.

[4] Duffy, T. M., Cunningham, D. J. (1996). Constructivism: Implications for the design and delivery of instruction, in: D.H. Jonassen (ed.), Educational Communications and Technology. p. 170-199. New York. 1996.

[5] Poole, B. J. (1997). Education for an information age. Teaching in the computerized classroom. Boston. 1997.

[6] Sutherland, R. (2004). Transforming teaching and learning: embedding ICT into everyday classroom practices, Journal of Computer Assisted Learning 20. p. 413-425. 2004.

[7] Kemmis, S., McTaggart, R. (2005). Participatory action research: Communicative action and the public sphere, in: N.K. Denzin \& Y.S. Lincoln, (eds), The Sage handbook of qualitative research. p. 559-603. Thousand Oaks, CA. 2005.

[8] Ngwenyama, O. K. (2002). The critical social theory approach to information systems: Problems and challenges, in: H-E. Nissen, H. K. Klein, R. A. Hirschheim, (eds), Information Systems Research: Contemporary Approaches and Emergent Traditions. pp. 267-280. Amsterdam. 1991. Reprinted in: M. D. Myers, and D. E. Avison, (eds), Qualitative Research in Information Systems: A Reader, London. 2002.

[9] Posch, P. (2003). Action Research in Austria: a review, Educational Action Research 11 (2), 233-246. 2003.

[10] Burr, V. (1998). An introduction to Social Constructionism, London \& New York. 1998.

[11] Mattozzi, I. (2006). The historical culture: A model of construction. Faenza. 2006.

[12] Barton, K. C., Levstik, L. S. (2004). Teaching History for the Common Good. Mahwah, New Jersey. 2004.

[13] Hoepper, B. (2009). Stand inside my shoes: developing historical empathy, QHistory. p. 34-39. 2009.

[14] Davis Jr, O. L., Yeager, E. A., Foster, S. J. (2001). Historical Empathy and Perspective Taking in the Social Studies, Oxford, England. 2001.

[15] Pattiz, A. E. (2004). The Idea of History Teaching: Using Collingwood's Idea of History to Promote Critical Thinking in the High School History Classroom, The History Teacher 37 (2), 239-249. February, 2004. 